\title{
Lietuvos upių šilumos ištekliai ir jų daugiametẻ kaita
}

\section{Jonas Jablonskis,}

\section{Aldona Jurgelènaitè,}

\author{
Aldona Tomkevičienè \\ Lietuvos energetikos institutas, \\ Breslaujos g. 3, \\ LT-44403 Kaunas \\ El.paštas: aldona@mail.lei.lt
}

\begin{abstract}
Straipsnis skirtas ištirti vieną iš atsinaujinančių energijos išteklių - upių vandens šilumą. Upių šilumos ištekliai, kaip vandens debito ir vandens temperatūros matas, gali būti naudojami apibūdinti upès baseino reakciją ị klimato kaitą. Jie kinta priklausomai nuo sezono ir upès hidrologinio režimo. Vadovaujantis vidutiniais mėnesiniais vandens debito ir vandens temperatūros duomenimis, 1951-2010 m. laikotarpiu išanalizuotas šilto periodo (gegužè-spalis) šilumos išteklių režimas ir kiekybiškai įvertinti jų pokyčiai, išryškinta šiluminių išteklių, vandens temperatūros bei vandens debitų daugiametė kaita. Tiriant Nemuno ties Smalininkais šilumos srautus nustatytas cikliškas kaitos pobūdis. Tirtuoju 1951-2010 m. laikotarpiu buvo išskirti du šilumos srauto kaitos ciklai, apimantys 23 (1954-1976) ir 28 (1977-2004) metų laikotarpius, kurių vidurkiai skiriasi nuo daugiamečio (1951-2005) vidurkio atitinkamai 3,1 ir $2,8 \%$. Buvo nustatyta, kad didžiausią ịtaką šilumos srautams formuotis turi upe tekančio vandens kiekis (vandens debitas). Šio straipsnio tikslas yra ịvertinti Lietuvos upių šilumos išteklius ir jų daugiametès kaitos pobūdị.
\end{abstract}

Raktažodžiai: upė, vandens debitas, vandens temperatūra, upių šilumos ištekliai

\section{IVADAS}

Didžioji upių tèkmès šiluminès energijos dalis gaunama su Saulès šilumos srautu. Nežymi šios energijos dalis ateina iš žemès gelmių (vandens-dugno sandūra), kita - susidaro tèkmès mechaninès energijos dèka (dèl trinties jègų) bei dèl kitų supančios aplinkos fizinių-klimatinių veiksnių [1]. Upių nuotèkis yra atmosferos kritulių, kurie susiformuoja išgaravus vandeniui nuo žemès paklotinio paviršiaus ir vandens telkinių, mažesnioji dalis. Šio proceso varomoji jèga yra šiluminė energija, kuri atlieka milžinišką darbą išgarindama vandeni, formuodama kritulius, dalyvaudama hidrocheminiuose ir hidrobiologiniuose procesuose bei savaiminiame vandens apsivalyme, vandens srautuose stimuliuodama gyvuosius organizmus [2-4]. Be to, upių vandens kaip ir žemès šiluma yra atsinaujinantys energijos ištekliai, vis plačiau naudojami praktikoje. Upių ir kitų vandens telkinių šiluma naudojama pastatams šildyti šilumos siurbliais [5-6], tačiau šių dienų technologijų ribotumas siaurina jų naudojimo galimybes dèl žemos vandens temperatūros šaltuoju metų laikotarpiu. Energijos išteklių trūkumas Lietuvoje - didelè problema, todèl ją sprendžiant reikètų daugiau plètoti atsinaujinančių išteklių energetikos technologijas. Esant tankiam upių tinklui bei vadovaujantis pasauline praktika, perspektyvoje galètų būti naudojama upių vandenyje esanti šiluma. Upių šilumos nuotèkis yra vienas iš ežerų ir tvenkinių šilumos balanso komponentų. Prie vandens telkinio pastačius šilumines bei atomines elektrines, skaičiuojamas ežero šilumos balansas, kad būtų galima ịvertinti elektrinių poveikį vandens šiluminiam režimui [7]. Todèl svarbu ištirti upėmis nešamos šilumos kiekį (šiluminį nuotèkį) ir jo daugiametę kaitą.

Šilumos kiekis upeje priklauso nuo jos vandeningumo ir vandens temperatūros bei kinta priklausomai nuo jų režimo. Tëkmès kryptis ir hidrografinio tinklo struktūra sąlygoja šilumos srauto pokyčius pagal upès tėkmę, 
sušvelnina ledo susidarymo sąlygas žiotyse ir daro ịtaką upés slėnio klimato sąlygoms [7]. Reikšmingi upès šilumos srauto pokyčiai gali būti intakų ịtekẻjimo vietose. Sąlyginai šiltas upių vanduo švelnina aplinkos mikroklimatą, o mažai mineralizuotas ir palyginti švarus ị̌silęs upių vanduo plačiai naudojamas buitinėms, gamybinèms bei rekreacinèms reikmėms.

Daug tyrimų atlikta ịvertinant didžiųjų Rusijos upių termini režimą, ledo reiškinius bei šiluminį nuotèkị. Tirtas Volgos, Šiaurès Dvinos, Pečioros, Vičegdos, Mizenès, Obės, Jenisiejaus, Kolymos, Lenos ir kitų upių šiluminis nuotèkis siekiant išaiškinti, kaip upių šiluminis nuotekis veikia Arkties vandenyno terminị režimą ir kokị poveikị šiluminiam nuotekiui turi hidroelektrinių ir jų kaskadų statyba [8-11].

Ilgalaikiai Lenos upès šiluminio nuotėkio pokyčiai šiltuoju metų laiku (birželis-rugsèjis) pateikti [8] darbe. [10] darbe buvo invertinta Volgos vandens nuotekio reguliavimo įtaka upés terminiam režimui ir šilumos ištekliams. Nustatyta, kad, sureguliavus Volgos vandens nuoteki, jos vidutinis šiluminis nuotèkis sumažèjo $16 \%$, o maksimalus padidejo $30 \%$.

Tokio pobūdžio tyrimai nuolat tęsiami. Apie tai byloja šiais metais (2013 07 24-25) Rybinske įvykusi IV konferencija, skirta Rusijos vandens telkiniu ledo reiškiniu ir vandens terminiams procesams aptarti. Šios konferencijos mokslo darbuose paskelbtas A. J. Šiklomanovo straipsnis [11], kuriame nagrinëjami Š. Dvinos, Obès, Jenisiejaus, Lenos, Janos, Kolymos žemupių ledo reiškiniai, vandens terminis režimas bei šiluminis nuotèis. Pagal sukauptus 1960-2001 m. duomenis, laisvo nuo ledo dangos periodo upių vandens temperatūros pametinèje kaitoje statistiškai reikšmingų trendų nenustatyta; upių vandens temperatūra kito nežymiai.

Nepaisant to, kad turime pakankamai duomenų apie Lietuvos daugelio upių vandens nuotèkị ir jo terminę būklę, šalies upių šilumos ištekliai nebuvo tirti. Daugiau dèmesio skirta Elektrẻnų marių ir Drūkšių ežero, kurių vanduo buvo naudojamas elektrinems aušinti [12-13], šiluminio balanso, kurio viena iš sudedamųjų yra šiluminis nuotekkis, tyrimui. Lietuvos upių terminio režimo tyrimai skelbti [1418] darbuose. Išnagrinèta Nemuno nuo aukštupio iki žiočių vandens temperatūra [14], jos režimo pokyčiai dèl nuotèkio reguliavimo [15], išaiškinti upių terminio režimo savitumai ir jų priežastys [16-18], tačiau šiuose darbuose upių vandens šilumos ištekliai nebuvo nagrinèjami. Pirmasis 1930 m. Nemuno terminio režimo ir ledo reiškinių tyrimus atliko S. Kolupaila [19].

Šio straipsnio tikslas - ịvertinti svarbesnių Lietuvos upių šilumos išteklius (šilumini nuotekị) pagal skelbtus 1951-2010 m. periodo šiltojo metu sezono (gegužè-spalis) vidutinius vandens nuotèkio ir vandens temperatūros duomenis, jų daugiametę kaitą ir kaitos pobūdị.

\section{PRADINIAI DUOMENYS IR METODIKA}

Upių igyta šiluma pernešama kartu su vandens tẻkme, todèl ją tiriant būtini upès vandens nuotèkio ir temperatūros duomenys. Hidrologiniu požiūriu Lietuvos upès stacionariai ištirtos pakankamai gerai. Iki $2010 \mathrm{~m}$. ịvairiais periodais veikè 130 vandens matavimų stočiu (VMS), kurių duomenys paskelbti Hidrologijos metraščiuose [20]. Vandens temperatūra Nemune (Kauno VMS) pradèta matuoti nuo 1928 m., o kitose Lietuvos upèse - nuo 1945 m. Ledo reiškiniai ir vandens lygis Smalininkuose fiksuojami nuo $1811 \mathrm{~m}$. [21]. Tyrimui panaudoti Lietuvos hidrometeorologijos tarnybos VMS išmatuoti bei Hidrologijos metraščiuose paskelbti upių vandens debitų ir temperatūros duomenys.

Upès vandens šilumos kiekị apibūdina jo temperatūra ir upès nuotèkis (debitas). Upès vandens temperatūra matuojama 8 ir 20 valandomis $0,1-0,5 \mathrm{~m}$ gylyje. Matavimu vidurkis apibūdina turbulentiškai susimaišiusios vandens tèkmès vidutinę temperatūrą. Kiekvienoje VMS vandens debitai apskaičiuojami pagal išmatuotus debitus ir stebètus vandens lygius bei sudarytas vandens debito $Q=f(h)$ kreives.

Šiltuoju metų laiku Lietuvos upemis nuteka apie 30$40 \%$ metinio nuotèkio, per likusius 6 mènesius (lapkritisbalandis) nuteka didesnè metinio nuotèkio dalis, tačiau vandens temperatūra žema. Pagal kadastrinius duomenis [22], Nemune ties Smalininkais žemesnè nei $0,2{ }^{\circ} \mathrm{C}$ vandens temperatūra vidutiniškai stebima nuo gruodžio 16 iki kovo 27 d., lapkričio-gruodžio dekadų temperatūra yra $0,6-5,0^{\circ} \mathrm{C}$. Balandžio mèn. vandens temperatūra pakyla iki $6,2{ }^{\circ} \mathrm{C}$, ir pavasariniai vandens šilumos srautai daro ittaką ledo procesams tiek Nemune, tiek kitose upèse.

Siekiant vienodumo ir vadovaujantis Pasaulinès meteorologijos organizacijos (PMO) rekomendacijomis, skaičiavimai buvo atlikti dešimtmečiams, trisdešimtmečiui (1961-1990), kuris laikomas pasaulinio klimato norma (standartine klimato norma), ir daugiamečiam periodui. Dèl klimato kaitos iqvertinimo buvo analizuojami 19512010 m. (šešių dešimtmečių) laikotarpio duomenys.

Tyrimui buvo parinktos didžiosios Lietuvos upès bei VMS, turinčios ilgas nuotekio ir vandens temperatūros stebejimų duomenų eiles. Tai Nemunas ties Druskininkais (1), Nemajūnais (2), Kaunu (3) ir Smalininkais (4), Merkys ties Puvočiais (5), Neris ties Jonava (6), Jūra ties Taurage (7), Mūša ties Ustukiais (8) ir Venta ties Leckava (9) (1 pav.). Šių upių baseinai apima visą Lietuvos teritoriją ir ivairaus terminio režimo upes [16], todèl pagal jas galime spręsti apie Lietuvos upių vandens šilumos režimą.

Upe plukdomos šilumos kiekis buvo apskaičiuotas pagal formulę $[7,11]$ :

$Q_{t}=c \cdot \rho \cdot Q \cdot T \cdot t ;$ 


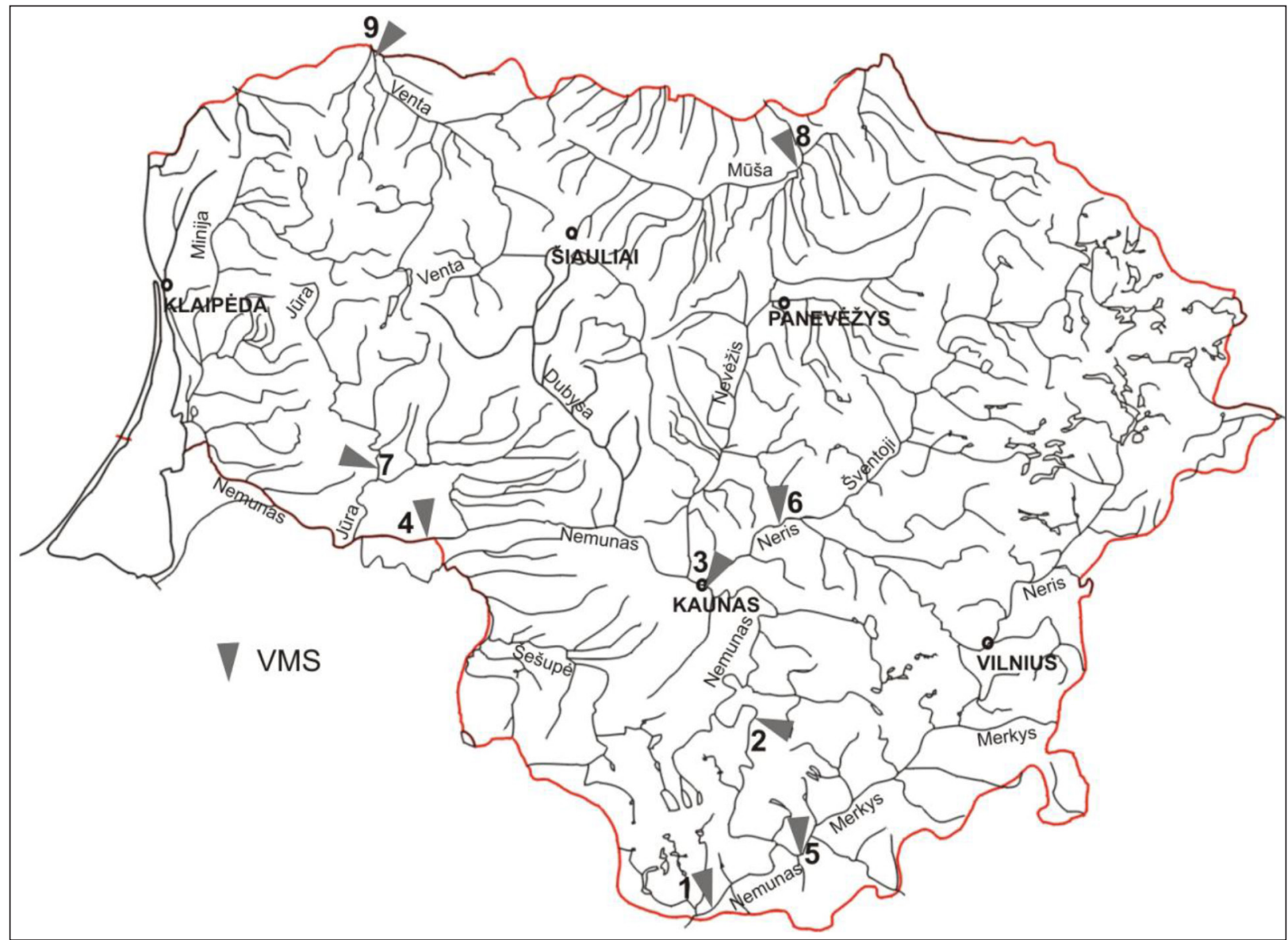

1 pav. Tirtų upių vandens matavimo stotys (VMS)

kur $c$ - vandens šiluminè talpa $(c=4,187 \mathrm{~kJ} / \mathrm{kg} \cdot \mathrm{K}$, kai vandens $\left.t=14{ }^{\circ} \mathrm{C}\right) ; \rho$ - vandens tankis, $\mathrm{kg} / \mathrm{m}^{3} ; Q$ - vandens debitas, $\mathrm{m}^{3} / \mathrm{s} ; T$ - vandens temperatūra, ${ }^{\circ} \mathrm{C} ; t$ - laiko intervalas, s. Pagal (1) formulę galima apskaičiuoti šilumos kiekį $Q_{i}$ pratekantị upe per laiko intervalą $t$.

\section{REZULTATŲ APTARIMAS}

Pagal dešimtmečių duomenis (lentelè) matyti, kad beveik visų upių 1951-1960, 1971-1980 ir 1981-1990 m. nuotèkis buvo didesnis už daugiametę normą, o 1961-1970, 1991-2000 ir 2001-2010 m. - mažesnis. Vandens temperatūra šiais dešimtmečiais nuotèkio atžvilgiu kito asinchroniškai. Tai rodo, kad atskirais laikotarpiais upès vandens temperatūra yra žemesnè, kai upè vandeningesnè, 0 kai ji mažiau vandeninga, tada jos vandens temperatūra yra aukštesné; paprastai upéje vandens temperatūra dèl objektyvių priežasčių didėja pagal upès tèkmę [16].

Nemuno ties Smalininkais 1961-1990 m. šiltojo metu sezono vandens debito, vandens temperatūros bei Vilniaus MS oro temperatūros duomenų palyginimas parodè, kad tarp debito ir vandens temperatūros koreliacijos koeficientas $r=-0,573$, oro temperatūros ir debito $r=-0489$, o tarp oro ir vandens temperatūrų $r=0,880$. Panašūs ryšiai gauti tarp kitų upių debitų ir vandens temperatūros. Iš čia matyti, kad klimatiniu požiūriu nuotèkis statistiškai neigiamai susijęs tiek su vandens, tiek su aplinkos oro temperatūromis.

Lentelejje pateikti Nemuno, jo didesnių intakų, taip pat Mūšos ir Ventos upių atskirų laikotarpių vandens šilumos srautai (W), šilumos nuotekis (Wh) ir savitoji šiluminè energija $\left(\mathrm{J} / \mathrm{m}^{3}\right)$. Apskaičiavus Nemuno ir jo didesnių intakų vandens šilumos išteklius, nustatyti dideli jų kiekiai. Šiltuoju metų laiku Nemune, Neryje, Jūroje, Ventoje ir Mūšoje 1 kubiniame metre vandens sukaupiama iki 65-68 MJ $/ \mathrm{m}^{3}$ šilumos, vèsesnio vandens Merkio upeje $56 \mathrm{MJ} / \mathrm{m}^{3}$, o šilčiausią mènesị (liepą) Nemune šis rodiklis siekia $85 \mathrm{MJ} / \mathrm{m}^{3}$.

Lentelëje matyti, kad Nemuno ties Smalininkais šiltojo metų sezono vidutinè srauto šiluminė galia buvo $26,6 \mathrm{GW}$, o liepą - 29,3 GW. Imant absoliučiais dydžiais, šilumos srautas priklauso nuo upés vandeningumo ir vandens temperatūros, o šilumos nuotèkis arba šilumos atsargos dar ir nuo laiko trukmès. Nemuno ties Smalininkais plukdomas kasmetines šilumos atsargas sudaro 117,8 TWh (lentele). Tuos skaičius galime palyginti su turimais kasmetiniais vèjo kinetinès energijos ir upių vandens potencinès energijos ištekliais bei energijos sąnaudomis. Turimais duomenimis, maksimalūs Lietuvos vèjo energijos metų 
Lentelè. Šiltojo metų laikotarpio (gegužè-spalis) upių vandens debitai $Q \mathrm{~m}^{3} / \mathrm{s}$ ir vandens temperatūra $t^{\circ} \mathrm{C}$, vandens šilumos srautai $q_{t}(\mathrm{~J} / \mathrm{s}, \mathrm{W})$ bei ištekliai (Wh ir $\mathrm{J} / \mathrm{m}^{3}$ )

\begin{tabular}{|c|c|c|c|c|c|c|c|c|c|c|}
\hline \multirow[b]{2}{*}{ Upé - VMS } & \multirow{2}{*}{$\begin{array}{c}\text { Baseino } \\
\text { plotas A } \\
\text { km² }^{2}\end{array}$} & \multirow{2}{*}{$\begin{array}{l}\text { Charak- } \\
\text { teristikos }\end{array}$} & \multicolumn{8}{|c|}{ Metai } \\
\hline & & & $\begin{array}{c}1951- \\
1960\end{array}$ & $\begin{array}{c}1961- \\
1970\end{array}$ & $\begin{array}{c}1971- \\
1980\end{array}$ & $\begin{array}{c}1981- \\
1990\end{array}$ & $\begin{array}{c}1991- \\
2000\end{array}$ & $\begin{array}{c}2001- \\
2010\end{array}$ & $\begin{array}{c}1961- \\
1990\end{array}$ & $\begin{array}{c}1951- \\
2010\end{array}$ \\
\hline \multirow{5}{*}{ Nemunas - Druskininkai } & \multirow{5}{*}{37100} & $Q \mathrm{~m}^{3} / \mathrm{s}$ & 157,4 & 157,9 & 179,4 & 174,4 & 157,4 & 159,1 & 170,6 & 166,5 \\
\hline & & $t^{\circ} \mathrm{C}$ & 16,10 & 16,27 & 15,73 & 16,12 & 16,32 & 17,20 & 16,04 & 16,29 \\
\hline & & $\mathrm{GJ} / \mathrm{s}(\mathrm{W})$ & 10,6 & 10,8 & 11,8 & 11,8 & 10,8 & 11,5 & 11,5 & 11,4 \\
\hline & & TWh & 46,9 & 47,6 & 52,3 & 52,1 & 47,6 & 50,7 & 50,7 & 50,2 \\
\hline & & $\mathrm{MJ} / \mathrm{m}^{3}$ & 67,5 & 68,2 & 65,8 & 67,5 & 68,4 & 72,1 & 67,2 & 68,3 \\
\hline \multirow{5}{*}{ Nemunas - Nemajūnai } & \multirow{5}{*}{42800} & $Q \mathrm{~m}^{3} / \mathrm{s}$ & 208,3 & 192,6 & 226,3 & 217,8 & 198,6 & 196,7 & 212,2 & 206,7 \\
\hline & & $t^{\circ} \mathrm{C}$ & 15,88 & 15,88 & 15,23 & 15,66 & 15,96 & 16,45 & 15,59 & 15,84 \\
\hline & & $\mathrm{GJ} / \mathrm{s}(\mathrm{W})$ & 13,9 & 12,8 & 14,4 & 14,3 & 13,3 & 13,6 & 13,9 & 13,7 \\
\hline & & TWh & 61,3 & 56,6 & 63,8 & 63,2 & 58,7 & 59,9 & 61,3 & 60,6 \\
\hline & & $\mathrm{MJ} / \mathrm{m}^{3}$ & 66,5 & 66,5 & 63,8 & 65,6 & 66,9 & 68,9 & 65,3 & 66,4 \\
\hline Nemunas - Kauno & $45800^{*}$ & $Q \mathrm{~m}^{3} / \mathrm{s}$ & 233,1 & 196,3 & 218,4 & 215,0 & 190,2 & 201,5 & 209,9 & 209,1 \\
\hline \multirow[t]{4}{*}{$\mathrm{HE}$ - Kaunas } & $46300^{* *}$ & $t^{\circ} \mathrm{C}$ & 16,35 & 16,22 & 15,71 & 15,93 & 16,36 & 16,95 & 15,95 & 16,25 \\
\hline & & $\mathrm{GJ} / \mathrm{s}(\mathrm{W})$ & 16,0 & 13,3 & 14,4 & 14,4 & 13,0 & 14,3 & 14,0 & 14,2 \\
\hline & & TWh & 70,6 & 59,0 & 63,5 & 63,4 & 57,6 & 63,3 & 62,0 & 62,9 \\
\hline & & $\mathrm{MJ} / \mathrm{m}^{3}$ & 68,5 & 68,0 & 65,8 & 66,7 & 68,5 & 71,0 & 66,8 & 68,1 \\
\hline \multirow{5}{*}{ Nemunas - Smalininkai } & \multirow{5}{*}{81200} & $Q \mathrm{~m}^{3} / \mathrm{s}$ & 422,9 & 367,5 & 403,4 & 431,1 & 372,6 & 376,0 & 400,7 & 395,6 \\
\hline & & $t^{\circ} \mathrm{C}$ & 16,05 & 16,08 & 15,62 & 15,94 & 16,21 & 16,32 & 15,88 & 16,04 \\
\hline & & $\mathrm{GJ} / \mathrm{s}(\mathrm{W})$ & 28,4 & 24,8 & 26,4 & 28,8 & 25,3 & 25,7 & 26,7 & 26,6 \\
\hline & & TWh & 125,7 & 109,5 & 116,7 & 127,3 & 111,9 & 113,6 & 117,8 & 117,5 \\
\hline & & $\mathrm{MJ} / \mathrm{m}^{3}$ & 67,2 & 67,4 & 65,4 & 66,8 & 67,9 & 68,4 & 66,5 & 67,2 \\
\hline \multirow{5}{*}{ Merkys - Puvočiai } & \multirow{5}{*}{4300} & $Q \mathrm{~m}^{3} / \mathrm{s}$ & 28,13 & 25,62 & 26,92 & 29,82 & 26,87 & 30,26 & 27,45 & 27,94 \\
\hline & & $t^{\circ} \mathrm{C}$ & 13,88 & 13,50 & 12,98 & 13,35 & 13,37 & 13,78 & 13,28 & 13,48 \\
\hline & & $\mathrm{GJ} / \mathrm{s}(\mathrm{W})$ & 1,64 & 1,45 & 1,46 & 1,67 & 1,51 & 1,75 & 1,53 & 1,58 \\
\hline & & TWh & 7,23 & 6,41 & 6,47 & 7,37 & 6,65 & 7,72 & 6,75 & 6,98 \\
\hline & & $\mathrm{MJ} / \mathrm{m}^{3}$ & 58,2 & 56,6 & 54,4 & 55,9 & 56,0 & 57,7 & 55,6 & 56,5 \\
\hline \multirow{5}{*}{ Neris - Jonava } & \multirow{5}{*}{24600} & $Q \mathrm{~m}^{3} / \mathrm{s}$ & 148,8 & 131,0 & 120,3 & 144,4 & 122,9 & 132,8 & 131,9 & 133,4 \\
\hline & & $t^{\circ} \mathrm{C}$ & 15,45 & 15,54 & 15,17 & 15,52 & 15,63 & 16,15 & 15,41 & 15,58 \\
\hline & & GJ/s (W) & 9,63 & 8,53 & 7,65 & 9,39 & 8,05 & 8,99 & 8,52 & 8,71 \\
\hline & & TWh & 42,6 & 37,7 & 33,8 & 41,5 & 35,6 & 39,7 & 37,6 & 38,5 \\
\hline & & $\mathrm{MJ} / \mathrm{m}^{3}$ & 64,7 & 65,1 & 63,6 & 65,0 & 65,5 & 67,7 & 64,6 & 65,3 \\
\hline \multirow{5}{*}{ Jūra - Tauragè } & \multirow{2}{*}{1690} & $Q \mathrm{~m}^{3} / \mathrm{s}$ & 11,34 & 8,67 & 12,75 & 13,13 & 8,69 & 11,20 & 11,52 & 10,95 \\
\hline & & $t^{\circ} \mathrm{C}$ & 15,82 & 15,71 & 15,27 & 15,41 & 15,90 & 16,37 & 15,46 & 15,75 \\
\hline & & $\mathrm{GJ} / \mathrm{s}(\mathrm{W})$ & 0,752 & 0,571 & 0,816 & 0,848 & 0,579 & 0,768 & 0,746 & 0,723 \\
\hline & & TWh & 3,32 & 2,52 & 3,61 & 3,75 & 2,56 & 3,40 & 3,30 & 3,20 \\
\hline & & $\mathrm{MJ} / \mathrm{m}^{3}$ & 66,3 & 65,8 & 64,0 & 64,6 & 66,6 & 68,6 & 64,8 & 66,0 \\
\hline \multirow{5}{*}{ Mūša - Ustukiai } & & $Q \mathrm{~m}^{3} / \mathrm{s}$ & - & 3,25 & 5,77 & 5,52 & 4,19 & 3,89 & 4,85 & $4,52^{* * *}$ \\
\hline & 2280 & $t^{\circ} \mathrm{C}$ & - & 15,40 & 15,13 & 15,55 & 15,70 & 16,33 & 15,36 & $15,62^{* * * *}$ \\
\hline & & $\mathrm{GJ} / \mathrm{s}(\mathrm{W})$ & - & 0,210 & 0,366 & 0,360 & 0,276 & 0,266 & 0,312 & 0,296 \\
\hline & & TWh & - & 0,927 & 1,62 & 1,59 & 1,22 & 1,18 & 1,38 & 1,31 \\
\hline & & $\mathrm{MJ} / \mathrm{m}^{3}$ & - & 64,5 & 63,4 & 65,2 & 65,8 & 68,4 & 64,4 & 65,4 \\
\hline & & $Q \mathrm{~m}^{3} / \mathrm{s}$ & 11,34 & 8,67 & 12,75 & 13,13 & 8,69 & 11,20 & 11,52 & 10,96 \\
\hline Venta - Leckava & & $t^{\circ} \mathrm{C}$ & 15,82 & 15,71 & 15,27 & 15,41 & 15,90 & 16,37 & 15,46 & 15,75 \\
\hline & 1690 & $\mathrm{GJ} / \mathrm{s}(\mathrm{W})$ & 1,02 & 0,735 & 1,15 & 1,29 & 0,816 & 0,838 & 1,06 & 0,975 \\
\hline & & TWh & 4,52 & 3,25 & 5,09 & 5,71 & 3,61 & 3,70 & 4,69 & 4,33 \\
\hline & & $\mathrm{MJ} / \mathrm{m}^{3}$ & 63,5 & 65,5 & 62,6 & 64,6 & 65,4 & 67,5 & 64,2 & 64,9 \\
\hline & & $Q \mathrm{~m}^{3} / \mathrm{s}$ & 308,9 & 281,3 & 360,5 & 397,5 & 358,2 & 364,5 & 346,4 & 345,1 \\
\hline & & $t^{\circ} \mathrm{C}$ & 20,67 & 19,84 & 19,58 & 19,59 & 20,25 & 21,43 & 19,67 & 20,23 \\
\hline Nemunas - smalınınkal & 81200 & GJ/s (W) & 26,8 & 23,4 & 29,6 & 32,6 & 30,4 & 32,7 & 28,5 & 29,3 \\
\hline & & TWh & 19,9 & 17,4 & 22,0 & 24,3 & 22,6 & 24,4 & 20,4 & 21,8 \\
\hline & & $\mathrm{MJ} / \mathrm{m}^{3}$ & 86,6 & 83,1 & 77,9 & 82,1 & 84,8 & 89,8 & 82,4 & 84,8 \\
\hline
\end{tabular}

* baseino plotas Kauno HE, kur matuojami vandens debitai;

** baseino plotas Kauno VMS, kur matuojama vandens temperatūra;

*** be 1951-1960 m. dešimtmečio (nematuota). 
teoriniai ištekliai sudaro $1000 \mathrm{MW}$ (2,63 TWh) [23], o upių potencinè energija - 5,13 TWh [24]. Lietuvoje $2012 \mathrm{~m}$. pirminès energijos sąnaudos sudare 7388,4 ktne (tonos naftos ekvivalento) [25] arba 85,9 TWh.

Apie šalies upių vandens šiluminių rodiklių kaitą galime spręsti pagal Nemuno hidrologinius ir temperatūros duomenis. Upių vandens ir jo temperatūros tyrimas igalina išryškinti jų hidrologini klimatini santyki ir jo apraiškas gamtiniuose procesuose, nes vandens srautai ir ju temperatūros yra klimatinių procesų rezultatas. Tai aiškiai matyti iš Nemuno ties Smalininkais šilumos srauto ir ji formuojančių veiksnių daugiametės kaitos grafikų (2 pav.). Grafikai sudaryti kasmet sumuojant nukrypimus nuo vidurkio. Kadangi tie nukrypimai yra ịvairių ženklų, todèl jų suma (kreives pradžia ir pabaiga) yra lygi nuliui, o kreivẻ rodo daugiametès kaitos pobūdị ir dydị 1951-2010 ir 1961-1990 m. vidurkių atžvilgiu (lentelè).

2 pav. grafikuose matyti, kad tiek nuotèkio, tiek vandens temperatūros duomenų sekos, tiek pagal jas apskaičiuoti vandens šilumos srautai, pamečiui išsidèstę cikliškai sinchroniškai $\left(Q\right.$ ir $\left.Q_{t}\right)$ arba cikliškai asinchroniškai $\left(t s u Q\right.$ ir $\left.Q_{t}\right)$. Upių šilumos srautų ir nuotèkio kaita cikliškai sinchroniška su statistiškai reikšmingomis $(\alpha=0,05)$ kaitos fazèmis. Sinchroniškiausiai svyruoja vandens debitas ir šiluminis nuotèkis $-r=0,98$, o tarp šiluminio nuotèkio ir vandens temperatūros $-r=-0,36$ (nekorektiškos koreliacijos). Tai rodo, kad Nemuno šiluminio nuotèkio kaitą labiau atspindi vandens debito kaitos pobūdis, nes nuotèkio ir jo temperatūros daugiametė kaita asinchroniška $(r=-0,57)$. Be to, Nemuno nuotekis statistiškai kinta labiau negu jo temperatūra, variacijos koeficientai atitinkamai $C_{v}=0,208$ (nuotèkio), $C_{v}=0,045$ (temperatūros) ir $C_{v}=0,197$ (šilumos srauto). Reikšmingų ilgalaikių trendų šiluminio nuotèkio daugiametèje kaitoje nenustatyta.

Nemuno ties Smalininkų VMS dešimtmečių šilumos srautus palyginus su daugiamečiu vidurkiu, skirtumas siekia 6,8 \% (1961-1990), tačiau klimatinè standartinė norma tik $0,4 \%$ aukštesnè už daugiametị vidurkị. 2 pav. (1) grafike išryškejja šios charakteristikos cikliškas kaitos pobūdis, kurị galima išreikšti absoliučiais dydžiais ir trukme. Tirtuoju 1951-2010 m. laikotarpiu išsiskiria du šilumos srauto kaitos ciklai, kurie apima 23 (1954-1976) ir 28 (1977-2004) metų laikotarpius. Ju vidurkiai skiriasi nuo daugiamečio (1951-2005) vidurkio atitinkamai 3,1 ir $2,8 \%$. Tačiau šių keturių cikliškų kaitos fazių, kurios apima 10-14 metų, vidurkiai reikšmingai $(\alpha=0,05)$ nukrypsta nuo daugiamečio vidurkio. Pavyzdžiui, 1964-1976 m. laikotarpiu - 14,4 \%, 1977-1990 m. daugiametị vidurki

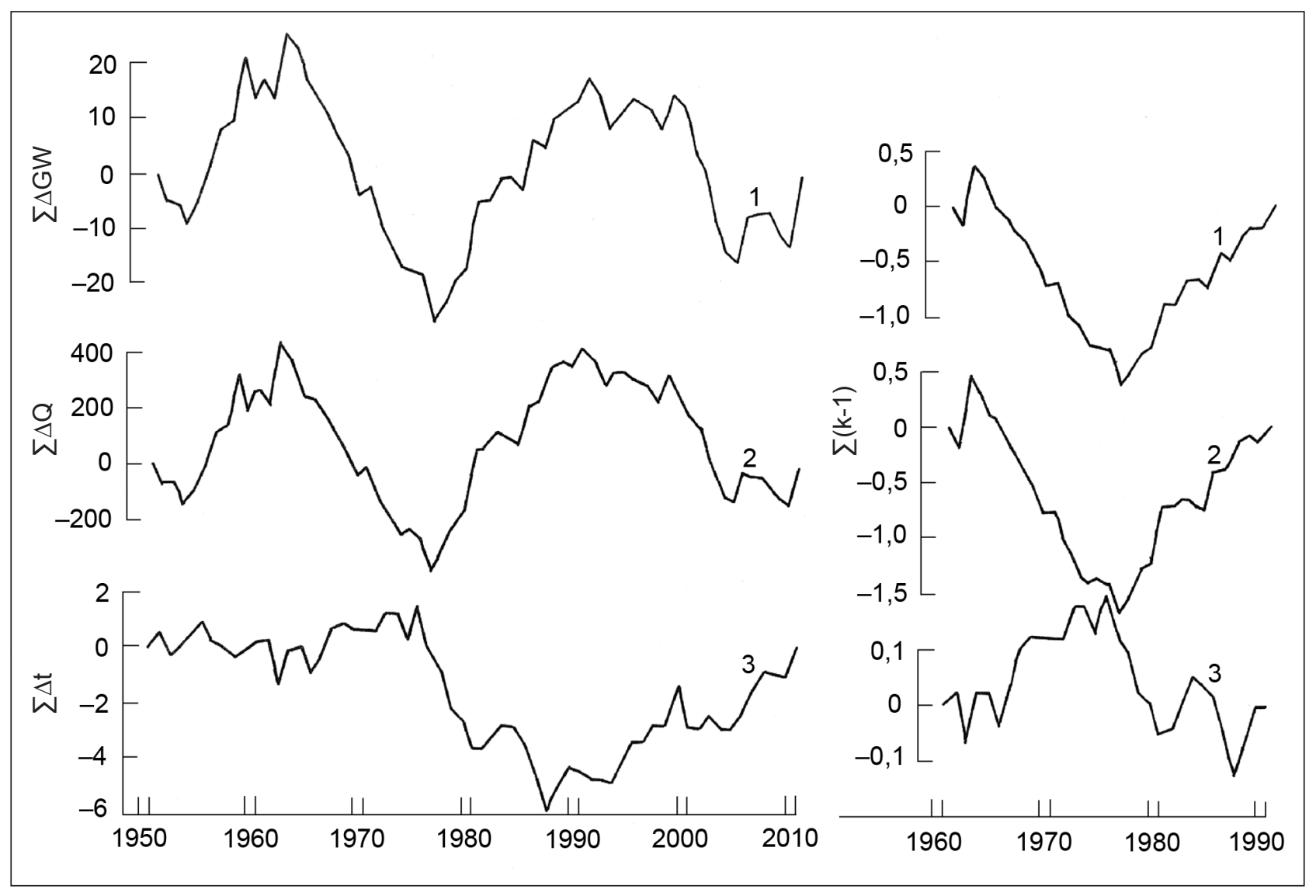

2 pav. Nemuno ties Smalininkais vandens šilumos srautai W - (1); vandens debitai $Q\left(\mathrm{~m}^{3} / \mathrm{s}\right)-(2)$; vandens temperatūrat $\left({ }^{\circ} \mathrm{C}\right)$ - (3) gegužès-spalio mèn. 
šilumos srautas viršijo 13,4 \%. Šios dvi fazès išsiskiria per visą stebėtą laikotarpi, o ypač standartinès normos (19611990) laikotarpiu. Kaip parodyta 2 pav. (2), (3) grafikuose, mažéjanti šilumos srauto fazè (1964-1976) susidaré esant mažesniam nuotèkiui ir aukštesnei jo vandens temperatūrai, o didejanti (1977-1990) - esant gausesniam nuotekiui ir žemesnei vandens temperatūrai. Šie atvejai rodo, kad šilumos srautams formuotis turi ittakos upe tekančio vandens kiekis, o pastarajam - temperatūra (taip pat ir oro). Atsižvelgiant ị hidrologinių elementų ciklišką kaitą galime daryti prielaidą, kad nuo 2008 m. prasidèjo nauja didesnio, bet vėsesnio upių nuotèkio ir šilumos srauto kaitos fazè.

Upių vandens temperatūrai turi ịtakos ir skirtingos vandens temperatūros intakų įtekejimas. Nemune tokia situacija stebima ísiliejus vėsesniam Merkio vandeniui. İvertinus vandens debitų ir temperatūrų skirtumus buvo gauta, kad Nemuno vandens temperatūra, ittekejjus Merkiui, sumažèja $0,4^{\circ} \mathrm{C}$.

Kaip rodo duomenys, upių nuotèkio šilumos srautu cikliškas kaitos pobūdis nekelia abejonių, tačiau tam tikrą poveikị upès terminiam režimui gali daryti ant upès ar šalia jos įrengti hidrotechniniai statiniai ir į upes patenkančios pramonès ir buities nuotekos. Lietuvos upèse irengta per 1000 tvenkiniu. Pagal tyrimu [26] duomenis nustatyta, kad beveik visais tirtais atvejais žemiau užtvankų tam tikru atstumu keičiasi ekologiškai svarbūs vandens rodikliai, taip pat ir upès terminis režimas.

Nemuno vandens ir jo šilumos srautams tiesioginès itakos turi Kauno HE. Terminis poveikis jaučiamas $16 \mathrm{~km}$ upès ruože iki Neries [14]. Lentelès duomenys rodo, kad visais atvejais vandens temperatūra Kauno VMS yra aukštesnè už Nemajūnų VMS ir žemiau esančių Lampèdžiu bei Smalininkų VMS atitinkamų laikotarpių vandens temperatūrą. Skirtumai siekia $0,3-0,4{ }^{\circ} \mathrm{C}$. Nustatyta, kad Nemuno ties Kaunu vandens temperatūrai ittakos turi Kauno HE ir Kauno miestas.

Natūrali vandens temperatūra teigiamai veikia daugelị gamtiniu procesų, tačiau gerokai padidejjusi šiluma vandenyje gali sukelti ir nepageidaujamų reiškinių. Nuolat yra atliekama vandens telkinių galimos šiluminès taršos kontrolè. Pagal gamtosaugos reikalavimus, ị vandens telkinį išleidžiamo vandens temperatūra šilčiausią mènesị neturi viršyti paskutinio dešimtmečio vidutinès vandens temperatūros $3{ }^{\circ} \mathrm{C}$, o žiemą $-5{ }^{\circ} \mathrm{C}$. Vadovaujantis šiomis normomis, buvo atliekama Drūkšių ežero šiluminès apkrovos kontrolè [15].

Praktiniu požiūriu reikètu vertinti ne tik vandens išteklių dydi, bet ir jų šiluminę vertę, kaip atsinaujinančios energijos šaltini. Tai galima pasiekti įvertinus hidromodulio $\left(1 / \mathrm{s} \cdot \mathrm{km}^{2}\right)$ šilumos srautą $\mathrm{W} / \mathrm{km}^{2}$. Jis parodo, koks šilumos srautas kartu su vandeniu nuteka iš upés baseino kvadratinio kilometro per sekundę. Š toms upèms galima nustatyti pagal lentelès duomenis.
Pavyzdžiui, Nemune ties Smalininkais, kur jo baseino plotas $81200 \mathrm{~km}^{2}$, tirtuoju 1951-2010 m. periodu (gegužèspalis) kartu su vandeniu ( $\left.Q=395,6 \mathrm{~m}^{3} / \mathrm{s}\right)$ vidutiniškai per ménesį tekèjo $q_{t}=0,328 \mathrm{MW} / \mathrm{km}^{2}$ šilumos srautas, (liepos mėnesi $q_{\mathrm{t}}=0,361 \mathrm{MW} / \mathrm{km}^{2}$ ), Merkiu ties Puvočiais daugiausia - 0,367 MW/ $\mathrm{km}^{2}$, o mažiausia Mūšoje ties Ustukiais - $0,130 \mathrm{MW} / \mathrm{km}^{2}$.

Upių vandens šilumos srautai ir šiluminès energijos atsargos jose - svarbus atsinaujinantis energijos šaltinis, dalyvaujantis įvairiuose fiziniuose-ekologiniuose procesuose, dar nepakankamai ištirtas ir vertinamas kompleksiškai naudojant upių vandens išteklius. Apibendrinti upių hidroterminiai duomenys leistų racionaliau panaudoti upių vandens išteklius. Duomenys apie Nemuno šiluminị režimą būtų naudingi ịvertinant statomos Baltijos $\mathrm{AE}$ aušinamo vandens poveikị upių hidroterminiam režimui.

\section{IŠVADOS}

1. Upių šilumos srautu ir nuotèkio kaita cikliškai sinchroniška, su statistiškai reikšmingomis $(\alpha=0,05)$ kaitos fazèmis; upiu šiluminio nuotèkio ir jo temperatūros kaita cikliškai asinchroniška, t. y. Nemuno šiluminis nuotèkis labiau priklauso nuo vandens debito, nei nuo vandens temperatūros, o jo šiluminio nuotekio kaitą labiau atspindi vandens debito kaitos pobūdis. Nemuno nuotèkis ir šilumos srautai statistiškai kinta labiau nei jo vandens temperatūra, variacijos koeficientai atitinkamai $C_{v}=0,208$ (nuotékio), $C_{v}=0,045$ (temperatūros) ir $C_{v}=0,197$ (šilumos srauto).

2. Apskaičiavus Nemuno ir jo didesnių intakų vandens šilumos išteklius, nustatyti dideli jų kiekiai. Šiltuoju metų laiku Nemune, Neryje, Jūroje, Ventoje ir Mūšoje šilumos sukaupiama iki $65-68 \mathrm{MJ} / \mathrm{m}^{3}$, vèsesnio vandens Merkio upèje - $56 \mathrm{MJ} / \mathrm{m}^{3}$, o šilčiausią mènesị liepą Nemune šis rodiklis siekia $85 \mathrm{MJ} / \mathrm{m}^{3}$.

3. Upių vandens šilumos srautai ir šiluminès energijos atsargos jose - svarbus atsinaujinantis energijos šaltinis, dalyvaujantis įvairiuose fiziniuose-ekologiniuose procesuose, dar nepakankamai ištirtas ir vertinamas kompleksiškai naudojant upių vandens išteklius.

Gauta 20130607 Priimta 20131220

\section{Literatūra}

1. Hammond D., Pryce A. R. Climate change impacts and water temperature. Science Report. 2007. P. 101.

2. Gore J. A., Mead J., Penczak T., Higler L., Kemp J. Processes influencing aquatic Fauna. Echohydrology: Processes Models and Case Studies. 2008. P. 62-87.

3. Morrill Jean C., Baes Roger C., Conklin Martha H. Estimating stream temperature from air temperature: 
Implications for future water quality. Journal of Environmental Engineering. 2005. Vol. 131. No. 1. P. 139-146.

4. Reiser S., Temming A., Eckhardt A., Hermann J.-P. Automation and critical evaluation of an annual chamber for aquatic ectotherm temperature preference experiments. Methods in Ecology and Evolution. 2013. P. 11.

5. Ding Y., Huang X., Wu X., Li B. Investment and economy analysis of water-source heat pump system in Chongqing, China. Journal of Renewable Energy. 2013. Vol. 2013, Article ID 574196. P. 5.

6. Qin Z., Tong M., Kun L. Experimental investigation on water quality standard of Yangtze River water source heat pump. Water Science \& Technology. 2012. Vol. 66. No. 5. P. 1103-1109.

7. Odrova T. V. Gidrofizika vodoemov sushi, 1979. $312 \mathrm{s.}$

8. Liu B., Yang D., Ye B., Berezovskaya S. Long-term openwater season stream temperature variations and changes over Lena River Basin in Siberia. Global and Planetary Change. 2005. Vol. 48. Issues 1-3. P. 96-111.

9. Magrickii D. V. Teplovoy stok ryek v morya Rossiyskoy Arktiki i ego izmeneniya. Vestnik Moskovskogo universiteta. Geografiya. 200909 05. S. 69-77.

10. Chernova J. V., Jolin M. M. Vliyanie zaregulirovaniya stoka Volgi na termicheskiy rezhim deltovykh vodotokov. Sovremennoe sostoyanie i strategii sokhraneniya prirodnykh resyrsov $i$ antropogennykh ekosistem: materialy vserossiysko nauchno-prakticheskoy konferentsii. 2010. S. 90-94.

11. Shiklomanov A. I. Izmeneniye ledovogo i termicheskogo rezhima v nizovyakh krupnykh rek basseyna Severnogo Ledovitogo okeana. Sbornik naychnykh trudov IV Vserossiyskoy konferentsii „Ledovye i termicheskie protsessy na vodnykh obektakh Rossii“. Moskva. 2013. S. 147-154.

12. Janukènienė R. Drūkšių ežero-aušintuvo kai kurie hidroterminiai aspektai. Energetika. 1994. Nr. 1. P. 9598.

13. Lasinskas M. I., Jablonskis J. S., Janukènienè R. J. Vliyanie teplovykh elektrostanciy na nekotorye gidrometeorologicheskie kharakteristiki vodoemov-okhladiteley. Ekologicheskie aspekty issledovaniy vodoyomov-okhladiteley AES. Moskva, 1983. S. 3-16.

14. Grižienè G. J., Čelkis G. J., Jablonskis J. S. Kharakteristiki temperatury vody reki Nemunas po dannym nabliudeniy 1945-1988 g. g. Lietuvos TSR Mokslu Akademijos darbai. B serija. 1983. T. 6(139). P. 43-52.

15. Meilutytè-Barauskienè D., Kovalenkovienè M., Šarauskiene $\mathrm{D}$. The impact of runoff regulation on the thermal regime of the Nemunas. Environmental Research, Engineering and Management. 2005. No. 4(34). P. 43-50.
16. Jablonskis J., Jurgelènaitė A. Vandens temperatūros Ł̇vairovès savitumai Lietuvos upèse. Energetika. 2010. Nr. 56(2). P. 163-171.

17. Vanagaitė J., Valiukevičius G. Lietuvos upių vandens temperatūros atitikimo ekologiniams reikalavimams ivertinimas. Geografija. 2011. Nr. 47(2). P. 62-70.

18. Jurgelènaitė A., Kriaučiūnienè J., Šarauskienè D. Spatial and temporal variation in the water temperature of Lithuanian rivers. BALTICA. 2012. Vol. 25. No. 1. P. 6576.

19. Kolupaila S. Nemuno užšalimai per 120 metų (18111930). Kosmos. 1930. Nr. 10-12. P. 299-305.

20. Hidrologinis metraštis 2010. Vilnius, 2011. 206 p.

21. Kolupaila S. Hidrometrinis metraštis II. Kaunas, 1930. $376 \mathrm{p}$.

22. Osnovnye gidrologicheskie kharakteristiki. Vyp. 3. Leningrad, 1978. T. 4. $216 \mathrm{~s}$.

23. Valstybinio audito ataskaita atsinaujinančiu energijos ištekliu potencialo naudojimas Lietuvoje. Vilnius: Lietuvos Respublikos valstybès kontrolè, 2010.63 p.

24. Jablonskis J., Punys P., Šavelskis V., Tautvydas A. Lietuvos mažosios hidroenergetikos žinynas. Kaunas, 1996. 204 p.

25. Lietuvos energetika 2012. Kaunas: LEI, 2013. 17 p.

26. Rimavičiūte E. Nuotèkio reguliavimo tvenkiniu ịtaka upių žemutiniams bjefams: daktaro disertacija. Kaunas, 2000. 126 p.

\section{Jonas Jablonskis, Aldona Jurgelènaitė, Aldona Tomkevičienė}

\section{HEAT RESOURCES IN THE WATER OF LITHUANIAN RIVERS AND THEIR TEMPORAL VARIATION}

\section{Summary}

The article is intended to explore one of the renewable energy resources - heat carried by the river water (heat runoff). River water heat runoff, as a synthetic measure of water discharge and water temperature, is useful to define the characteristics of watershed in response to climate change. River water potential heat resources calculated according to long-term (1951-2010) water discharge and water temperature data of the warm season of a year (May-October) are presented in this article. The data are provided for decades, for the period of climatological standard normal (1961-1990) and for the entire period of observations. The correlations between river water and its heat indicators as well as multi-annual fluctuations were analyzed. The cyclic nature of the change has been established by analysing the heat runoff of the Nemunas River at Smalininkai. Two cycles of heat runoff change, which included 23 (1954-1976) and 28 (1977-2004) years and which averages were different from the multi-annual average of $3.1 \%$ and $2.8 \%$, were released. The studied indicators are suggested 
to use when it is necessary to know not only the river water resources but also the heat content in the water.

Key words: river, water discharge, water temperature, heat resources

Йонас Яблонскис, Алдона Юргяленайте,

Алдона Томкявичене

ТЕПЛОВЫЕ РЕСУРСЫ РЕК ЛИТВЫ И ИХ

ИЗМЕНЕНИЕ

Резюме

Статья предназначена для изучения одного из возобновляемых источников энергии - теплового стока рек. Тепловой сток реки как синтетический показатель расхода и температуры воды можно использовать для описания бассейнового реагирования на изменение климата. Тепловой сток изменяется в зависимости от сезона и гидрологического режима реки. По данным речного стока и температуры воды за период 19512010 г. были рассчитаны величины теплового стока и теплового запаса в воде рек Литвы за теплый период года (майоктябрь). Данные представленные за десятилетия, за период климатической нормы (1961-1990) и за весь исследуемый период (1951-2010). Анализируя тепловой сток реки Нямунас (водомерная станция Смалининкай) был определен циклический характер его изменения. За анализируемый период 1951-2010 г. были выделены два цикла изменения теплового стока, которые включают 23 (1954-1976) и 28 (1977-2004) лет, средние значения теплового стока которых отличаються от многолетних значений в среднем на 3,1 и 2,8 \%, относительно. Проанализированы взаимоотношения между речным стоком и его тепловыми характеристиками и их многолетнее изменение. Исследуемые характеристики предлагаются использовать не только для оценки водных ресурсов, но и для оценки нагрева речных вод.

Ключевые слова: река, сток, температура воды, тепловой сток рек 